\title{
KEEFEKTIFAN PENGGUNAAN APLIKASI WINGEOM DALAM PEMAPARAN MATERI PELAJARAN DIMENSI TIGA
}

\author{
Ahmad Budi Sutrisno ${ }^{1}$, Atira ${ }^{2}$ \\ STKIP Andi Matappa ${ }^{1,2}$ \\ pos-el : ahmadbudisutrisno@stkip-andi-matappa.ac.id ${ }^{1}$, atiram1411@gmail.com²
}

\begin{abstract}
ABSTRAK
Tujuan penelitian yaitu: (1) Untuk mengetahui bagaimana hasil belajar siswa setelah menggunakan aplikasi Wingeom dalam pemaparan materi pelajaran dimensi tiga, (2) Untuk mengetahui bagaimana respon siswa terhadap pembelajaran dengan penggunaan aplikasi Wingeom dalam pemaparan materi dimensi tiga, (3) Untuk mengetahui bagaimana aktivitas siswa dengan pemaparan materi pelajaran dimensi tiga menggunakan aplikasi Wingeom, (4) Untuk mengetahui bagaimana pengelolaan pembelajaran dengan pemaparan materi pelajaran dimensi tiga menggunakan aplikasi Wingeom, (5) Untuk mengetahui apakah aplikasi Wingeom efektif digunakan dalam pemaparan materi pelajaran dimensi tiga. Penelitian ini menggunakan pendekatan kuantitatif terhadap 27 subjek penelitian yang merupakan siswa kelas XII MIA 1 di SMA Negeri 2 Pangkep. Pengumpulan data menggunakan instrument tes, angket dan observasi. Analisis data menggunakan analisis statistika deskriptif dan inferensial. Hasil penelitian ini menunjukkan bahwa: (1) Hasil belajar siswa dengan aplikasi Wingeom dalam pemaparan materi pelajaran dimensi tiga adalah baik, (2) Respon siswa saat proses pembelajaran berlangsung dengan penggunaan aplikasi Wingeom dalam pemaparan materi dimensi tiga adalah positif, (3) Aktivitas siswa saat proses pembelajaran berlangsung dengan pemaparan materi pelajaran dimensi tiga menggunakan aplikasi Wingeom adalah aktif, (4) Keterlaksanaan pembelajaran dengan pemaparan materi pelajaran dimensi tiga menggunakan aplikasi Wingeom adalah sangat baik, (5) Aplikasi Wingeom efektif digunakan dalam pemaparan materi pelajaran dimensi tiga.
\end{abstract}

Kata kunci : media, pembelajaran, Wingeom, keefektifan

\begin{abstract}
The research objectives are: (1) To find out how student learning outcomes after using Wingeom application in exposure to three-dimensional subject matter, (2) To find out how students respond to learning by using Wingeom application in exposure to three-dimensional material, (3) To find out how student activities with exposure to three-dimensional subject matter using Wingeom application, (4) To find out how to manage learning by exposing threedimensional subject matter using the Wingeom application, (5) To find out whether Wingeom application is effectively used in exposure to three-dimensional subject matter. This study uses a quantitative approach to 27 research subjects who are students of class XII MIA 1 in SMA Negeri 2 Pangkep. Data collection using test instruments, questionnaires and observations. Data analysis uses descriptive and inferential statistical analysis. The results of this study indicate that: (1) Student learning outcomes with the Wingeom application in exposure to the three dimensional subject matter are good, (2) Student responses during the learning process take place with the use of the Wingeom application in the exposure to the three dimensional material is positive, (3) Student activities when the learning process takes place with the presentation of three-dimensional subject matter using the Wingeom application is active, (4) The implementation of learning by exposing the three-dimensional subject matter using the Wingeom application is very good, (5) the Wingeom application is effectively used in exposure to the three-dimensional subject matter.
\end{abstract}

Keywords : media, learning, Wingeom, effectiveness 


\section{PENDAHULUAN}

Sebagai salah satu faktor internal yang mempengaruhi kualitas hasil belajar siswa, kecerdasan yang dimiliki oleh manusia terbagi atas delapan jenis yang dikemukakan oleh Howard Gardner dalam Novitasari \& Abdul Rahman (2015) yaitu: (1) kecerdasan linguistik (linguistic intelligence), (2) kecerdasan logis matematis (logical mathematic intelligence),

kecerdasan visual spasial (visual spatial intelligence), (4) kecerdasan musical (musical intelligence), (5) kecerdasan kinestetik (body kinesthetic intelligence), (6) kecerdasan interpersonal (interpersonal intelligence), (7) kecerdasan intrapersonal (intrapersonal intelligence), dan (8) kecerdasan natural (naturalistic intelligence) dimana setiap kecerdasan memilki karakteristik dan cirinya masing-masing yang membedakan setiap siswa.

Pada pembelajaran matematika, terutama untuk geometri ternyata kemampuan spasial sangat penting. Hal ini terbukti pada penelitian National Academy of Science (Faradhila, 2013) yang mengemukakan bahwa setiap siswa harus mengembangkan kemampuan dan penginderaan spasialnya yang sangat berguna dalam memahami relasi dan sifat-sifat dalam geometri untuk memecahkan masalah dalam kehidupan sehari-hari. Kemampuan spasial yang baik akan menjadikan siswa mampu mendeteksi hubungan dan perubahan bentuk bangun dalam geometri.

Dibalik kemampuan spasial yang baik dalam memahami konsep geometri yang dimliki siswa, tentu ada peranan penting dari seorang guru sebagai pelaksana pembelajaran. Namun dalam hal ini terkadang guru kesulitan dalam menjelaskan dan mengajarkan kepada siswa karena materi ini membutuhkan kemampuan visualisasi siswa yang relatif tinggi. Pada saat ini siswa dituntut untuk membayangkan sebuah bangun agar bisa memecahkan soal. Tidak hanya masalah kemampuan memvisualisasikan, namun juga pemahaman siswa akan istilah geometri juga bermasalah, hal ini dapat dilihat berdasarkan hasil pengamatan yang diperoleh pada saat menjalani masa PPL (magang 3) menunjukkan bahwa nilai harian siswa kelas XII MIA 4 cukup rendah. Hal ini dilihat dari hasil observasi siswa yang nilainya cukup rendah disebabkan karena mengalami kesulitan dalam pemahaman konsep, kesulitan dalam memahami gambar yang berkaitan dengan pengimajinasian. Selain itu, kejenuhan siswa pada media yang dipakai dalam belajar dan kurangnya kemampuan visualisasi gambar yang baik dalam pola pikir siswa yang menjadi kendala dalam meningkatkan hasil belajar siswa dan menghambat kemampuan kecerdasan yang dimliki siswa.

Untuk meningkatkan kemampuan memvisualisasi gambar khususnya pada materi bangun ruang diperlukan suatu strategi pembelajaran yang inovatif. Salah satunya adalah dengan pemanfaatan kemajuan Teknologi Informasi dan Komunikasi (TIK). Dengan pemanfaatan inovasi ini, akan memberikan efek pembelajaran yang lebih baik, menarik, dan efektif. Hal ini sehubungan dengan pendapat Glass (Arcat, 2014) menyatakan bahwa banyak sekali kontribusi nyata yang dapat dipersembahkan komputer bagi 
kemajuan pendidikan, khususnya pembelajaran matematika. Komputer dapat dimanfaatkan sebagai alat bantu dalam belajar dan dapat meningkatkan kreatifitas siswa sehingga siswa dapat mengoptimalkan kemampuan yang dimiliki meskipun setiap siswa memilki kemampuan yang berbeda-beda dalam menangkap suatu materi yang diajarkan.

Salah satu bentuk aplikasi komputer berbentuk perangkat lunak komputer matematika dinamik (Dynamic Mathematics Software) yang dapat digunakan dalam pembelajaran geometri yaitu aplikasi Wingeom. Windows Geometry atau yang disingkat dengan Wingeom banyak diguanakan untuk menyusun bahan ajar geometri, membuat gambar bangun datar, bangun ruang, animasi bangun ruang.

Program Wingeom ini dapat digunakan sebagai mindtools pada pembelajaran geometri, dimana siswa dapat menggunakannya untuk mengembangkan kreativitas imajinasinya, siswa dapat mengeksplorasi, mengamati, melakukan animasi bangun-bangun dan tampilan pada materi geometri. Salah satu fasilitas menarik yang dimiliki program ini adalah fasilitas animasi yang begitu mudah, misalnya benda-benda dimensi dua atau tiga dapat diputar sehingga visualisasinya akan tampak begitu jelas. Berdasarkan pendapat David Wees (Putra, 2013) menyatakan bahwa ada beberapa pertimbangan tentang penggunaan dynamic geometry software seperti Wingeom dalam pembelajaran matematika, khususnya geometri, yaitu memungkinkan siswa untuk aktif dalam membangun pemahaman geometri. Wingeom memungkinkan visualisasi sederhana dari konsep geometri yang cukup rumit dan membantu meningkatkan pemahaman siswa tentang konsep dasar geometri.

\section{METODE PENELITIAN}

Pendekatan penelitian yang digunakan adalah pendekatan kuantitatif. Jenis penelitian ini adalah penelitian pra eksperimen. Keefektifan penggunaan aplikasi dalam pemaparan materi dimensi tiga yang dimaksud dalam penelitian ini adalah suatu kondisi dimana setelah penggunaan aplikasi Wingeom ini, dalam memaparkan materi dapat meningkatkan pengetahuan konsep dasar matematika siswa khususnya pada materi dimensi tiga dengan kriteria keefektifan meliputi, hasil belajar, respon siswa, aktivitas siswa, dan keterlaksanaan pembelajaran. Penelitian ini dilaukuan di SMA Negeri 2 Pangkep. Pemilihan sampel dalam penelitian ini dengan teknik nonrandom sampling, karena diasumsikan populasi dan sampelnya sama/homogen yaitu kelas XII MIA 1 SMA Negeri 2 Pangkep.

Teknik pengumpulan data yang digunakan adalah sebagai berikut :

1. Data hasil belajar

Untuk memperoleh data tentang hasil tes setelah pelaksanaan pembelajaran. Tes yang diberikan adalah tes hasil belajar yang telah disusun dan direvisi berdasarkan validasi ahli dan praktisi.

2. Data respon siswa

Untuk memperoleh data respon siswa terhadap pembelajaran, digunakan angket respon siswa yang telah direvisi berdasarkan penilaian dan koreksi dari para ahli. Angket 
respon siswa diberikan kepada seluruh siswa yang menjadi subjek penilaian. Pemberian angket tersebut dilkukan setelah berakhirnya seluruh proses pembelajaran.

3. Data aktivitas siswa

Untuk memperoleh data aktifitas siswa dalam pembelajaran dilakukan pengamatan dengan menggunakan lembar observasi aktifitas siswa selama proses pembelajaran berlangsung dengan lembar observasi yang digunakan telah diberikan penilaian dan dikoreksi oleh validator. Pengamat diminta untuk menulis nomornomor kategori aktivitas siswa yang dominan muncul dalam setiap lima menit (empat menit mengamati, satu menit menulis nomor kategori yang muncul) mulai dari awal hingga akhir proses pembelajaran.

4. Data pengelolaan pembelajaran

Untuk memperoleh data pengelolaan pembelajaran yang dilakukan dalam proses pembelajaran dengan menggunakan bahan ajar yang telah disusun maka dilakukan pengamatan dengan menggunakan lembar observasi pengelolaan pembelajaran yang telah direvisi berdasarkan penilaian, saran, dan kritik yang membangun dari para validator. Pengamatan dilakukan dari awal hingga berakhirnya proses pembelajaran.

Teknik analisis data yang digunakan untuk menganalisis data yang diperoleh adalah dengan menggunakan analisis statistik deskriptif dan analisis statistik inferensial.

\section{HASIL DAN PEMBAHASAN}

\section{Hasil Analisis Deskriptif}

a. Hasil Belajar Siswa

Deskripsi tes hasil belajar setelah dilakukan pembelajaran dengan menggunakan aplikasi Wingeom dalam pemaparan materi pelajaran dimensi tiga selama tiga kali pertemuan. diperoleh bahwa rata- rata skor tes hasil belajar matematika siswa kelas XII MIA 1 dari 27 sampel adalah 78,20 dengan standar deviasai 7,357 yang berarti bahwa perbedaan nilai siswa dari rata-rata cukup jauh. Hal ini juga ditunjukkan dengan keberagaman data yang cukup tinggi yaitu 54,132, sedangkan skor tertinggi yaitu 92 dan skor terendah yaitu 61 yang berarti bahwa rentang data tersebut yaitu 30 dan dari data tersebut menunjukkan bahwa beberapa siswa memperoleh nilai yang sama yaitu nilai 79 hal ini ditunjukkan dari modus dari data yiatu 79.

Jika skor tes hasil belajar matematika siswa yang diajar dengan menggunakan aplikasi Wingeom dalam pemaparan materi dimensi tiga dikategorikan berdasar kolaborasi KKM dan permendikbud nomor 104 tahun 2014, diperoleh distribusi skor frekuensi menunjukkan bahwa jumlah siswa yang berada pada kategori/predikat sangat kurang sebanyak 0, jumlah siswa yang berada pada kategori/predikat kurang sebesar $7,41 \%$ atau sebanyak 2 orang, jumlah siswa yang berada pada kategori/predikat cukup sebanyak 16 orang $(59,26 \%)$, jumlah siswa yang berada pada kategori/predikat baik sebanyak 8 Orang $(29,63 \%)$, dan jumlah siswa 
yang berada pada kategori/predikat sangat baik sebanyak 1 orang $(3,7 \%)$. Dari data tersebut dapat disimpulkan bahwa dari 27 orang siswa kelas XII MIA 1 SMA Negeri 2 Pangkep yang di ajar dengan memanfaatkan media berupa aplikasi Wingeom dalam pemaparan materi pelajaran dimensi tiga, pada umumnya memiki tingkat hasil belajar matematika dalam kategori/predikat "Cukup".

Selanjutnya, dilakukan analisis ketuntasan belajar matematika siswa kelas XII MIA 1 SMA Negeri 2 Pangkep untuk menentukan ketuntasan individual dengan berpedoman pada kriteria ketuntasan minimal (KKM) matematika yang ditetapkan oleh sekolah yang bersangkutan berdasarkan kurikulum 2013 yang diberlakukan oleh sekolah tersebut. Analisis ketuntasan belajar matematika siswa terlihat bahwa siswa yang belum tuntas sebanyak 2 orang $(7,41 \%)$ sedangkan siswa yang memenuhi ketuntasan individu sebnayak 25 orang (92,59\%), sehingga dapat dikatakan bahwa pada pembelajaran dengan pemanfaatan media berupa aplikasi Wingeom dalam pemaparan materi pelajaran dimensi tiga pada siswa kelas XII SMA Negeri 2 Pangkep memenuhi kriteria ketuntasan klasikal yaitu > 85\%, dan artinya telah mencapai efektivitas hasil belajar siswa.

b. Respon Siswa

Data respon siswa terhadap pembelajaran yang menggunakan media berupa aplikasi Wingeom dalam pemaparan materi pelajaran dimensi tiga diperoleh dengan angket respon siswa pada kelas XII MIA 1.
Angket ini diberikan kepada siswa setelah mengikuti kegiatan pembelajaran selama 3 kali pertemuan. Siswa yang memberi respon tidak positif adalah $0(0 \%)$, siswa yang memberi respon kurang positif adalah 1 orang $(3,7 \%)$, siswa yang memberi respon positif adalah 21 orang $(77,8 \%)$, dan siswa yang memberi respon sangat positif adalah 5 orang $(18,5 \%)$. Dapat dikatakan bahwa respon siswa terhadap pembelajaran matematika dengan pemanfaatan media berupa aplikasi Wingeom dalam pemaparan materi dimensi tiga dikatakan efektif karena total respon positif > 70\%, yaitu sebesar $77,8 \%$ atau 21 orang dan total respon sangat positif sebesar $18,5 \%$ atau 5 orang

c. Aktivitas Siswa

Instrumen yang digunakan untuk memperoleh data tentang aktivitas siswa adalah lembar pengamatan aktivitas siswa yang digunakan untuk mengamati semua aktivitas siswa selama kegiatan pembelajaran berlangsung dengan menggunakan media berupa aplikasi Wingeom dalam pemaparan materi pelajaran dimensi tiga. Pengamatan aktivitas siswa hanya difokuskan pada kelompok satu yang telah ditentukan oleh peneliti sebagai fokus penelitian.

Pengamatan dilakukan oleh satu orang pengamat mengamati lima siswa yang dipilih dari perwakilan masing- masing kelompok. Berikut ini adalah data hasil pengamatan aktivitas siswa yang dilakukan oleh observer. 
1) Siswa memperhatikan tujuan pembelajaran yang disampaikan guru

2) Menyimak dengan seksama informasi yang disampaikan guru

3) Menyimak dengan seksama penjelasan guru tentang materi dimensi tiga dengan menggunakan media aplikasi Wingeom dalam pemaparan materinya

4) Siswa terampil memanfaatkan fitur (tampilan bangun ruang) aplikasi Wingeom dalam materi dimensi tiga untuk menyelesaikan soal

5) Membaca atau menyimak masalah serta aktivitas pada LKS

6) Berdiskusi untuk menemukan cara penyelesaian setiap soal pada LKS, menulis alternatif jawaban dan membandingkan jawaban dalam diskusi kelompok/ kelas

7) Bertanya/menyampaikan pendapat/ide kepada teman/guru

8) Melakukan kegiatan lain diluar tugas, misalnya tidak memperhatikan penjelasan guru atau melakukan aktivitas yang tidak berkaitan dengan KBM (tidur, bermain ponsel, ngobrol, melamun)

Secara umum berdasarkan hasil analisis data aktivitas siswa dari 5 siswa yang menjadi fokus, diketahui bahwa aktivitas siswa dikatakan efektif karena rata-rata total presentase aktivitas siswa dalam
KBM untuk (tujuh kategori aktivitas siswa yang dikehendaki) mencapai kriteria sangat aktif dengan prosentase sebesar 96,3\%

d. Pengelolaan Pembelajaran

Data keterlakasanaan pengelolaan pembelajaran dengan pemanfaatan media berupa aplikasi Wingeom dalam pemaparan materi pelajaran dimensi tiga diperoleh dengan menghitung rata-rata nilai keseluruhan tiap aspek yang diamati, sehingga diperoleh skor rata-rata sebesar 4,39, kemudian skor tersebut dihitung dengan menggunakan rumus berikut :

$\mathrm{pp}=\frac{\text { skor yang diperole } h}{\text { skor maksimal }} \times 4$ sehingga, diperoleh nilai 3,512. Tingkat kemampuan guru dalam mengelola pembelajaran masuk ke dalam kategori sangat baik dengan perolehan skor 3,512 dan dapat dikatakan bahwa pengelolaan pembelajaran dengan pemanfaatan media berupa aplikasi Wingeom mencapai tingkat keefektifan pengelolaan pembelajaran karena berada pada kategori sanagat baik.

e. Keefektifan pembelajaran

Berdasarkan hasil analisis deskriptif untuk 4 indikator keefektifan pembelajaran dengan penggunaan aplikasi wingeom dalam pemaparan materi pelajaran dimensi tiga dirangkum pada tabel berikut ini:

Tabel 1. Data Hasil Analisis Deskriptif

\begin{tabular}{|c|l|c|c|}
\hline $\begin{array}{c}\text { Indikator } \\
\text { keefektifan }\end{array}$ & \multicolumn{1}{|c|}{ Standar pengukuran } & Hasil penelitian & Keterangan \\
\hline Hasil belajar siswa & $\begin{array}{l}\text { Tuntas individual dengan KKM } \\
\geq 70 \text { dan tuntas klasikal } \geq 85 \%\end{array}$ & $92,59 \%$ & Baik \\
\hline Respon siswa & $\begin{array}{l}\text { Total respon positif \& sangat } \\
\text { positif } \geq 70 \%\end{array}$ & $96,3 \%$ & Positif \\
\hline Aktivitas siswa & $\begin{array}{l}\text { Total rata- rata aktivitas yang } \\
\text { terlaksana dengan rentang waktu } \\
\text { yang ditentukan } \geq 80 \%\end{array}$ \\
\hline
\end{tabular}




$\begin{aligned} & \text { Pengelolaan } \\ & \text { pembelajaran }\end{aligned}$
Berdasarkan Tabel 1 terlihat
perolehan skor
pemwa 4 indikator keefektifan
dapat disimpulkan bahwa apabila
semua indikator keefektifan
terpenuhi maka aplikasi Wingeom
efektif digunakan dalam pemaparan
materi pelajaran dimensi tiga.

\section{Hasil Analisis Inferensial}

1) Uji Normalitas

Setelah dilakukan pengolahan data, hasil uji normalitas menggunakan kolmogrov-smirnov data hasil belajar matematika peserta didik kelas XII MIA 1 diperoleh bahwa nilai tes hasil belajar siswa kelas XII MIA 1 yang diajar menggunakan aplikasi Wingeom dalam pemaparan materi pelajaran dimensi tiga dari sig. yang dicapai yaitu $0,200>0,05$. Jadi, data dengan nilai tersebut dinyatakan berdistribusi normal.

2) Uji t

Uji Hipotesis menggunkan uji $\mathrm{t}$ yang dilakukan dengan syarat data yang diteliti adalah normal. Pengujian hipotesis dimaksudkan untuk keefektifan penggunaan aplikasi Wingeom dalam pemaparan materi pelajaran dimensi tiga kelas XII MIA 1. Uji dilakukan dengan menggunakan uji one sample t test.

- Jika nilai $t_{\text {hitung }}>\mathrm{t}_{\text {tabel }}$ maka $\mathrm{H}_{0}$ ditolak

- Jika nilai $\mathrm{t}_{\text {hitung }}<\mathrm{t}_{\text {tabel }}$ maka $\mathrm{H}_{0}$ diterima

Rumus mencari $\mathrm{t}_{\text {tabel }}=0,005 / 2 ; \mathrm{df}$

$$
=(0,025 ; 26)
$$

Kemudian lihat pada distribusi nilai $t_{\text {tabel }}$ statistic, Maka diperoleh $t_{\text {tabel }}$
Sangat baik

sebesar 2,056. Diperoleh $t_{\text {hitung }}$ sebesar 5,7942 > $\mathrm{t}_{\text {tabel }} 2,056$, maka $\mathrm{H}_{0}$ ditolak. Sehingga dapat disimpulkan bahwa aplikasi Wingeom efektif digunakan dalam pemaparan materi pelajaran dimensi tiga pada siswa kelas XII MIA 1 SMA Negeri 2 Pangkep.

\section{Pembahasan}

Berdasarkan hasil penelitian yang diperoleh untuk tes hasil belajar matematika siswa kelas XII MIA 1 yang diajar dengan menggunakan aplikasi Wingeom dalam pemaparan materi dimensi tiga terdapat 25 orang siswa yang mencapai ketuntasan secara individual dengan KKM 70 dari 27 orang siswa, sehingga dikatakan memenuhi ketuntasan klasikal yaitu $(92,59 \%)>$ batas ketuntasan klasikal (85\%) dan artinya telah mencapai efektivitas hasil belajar siswa.

Untuk data ata angket respon siswa dapat dikatakan bahwa respon siswa terhadap pembelajaran matematika dengan pemanfaatan media berupa aplikasi Wingeom dalam pemaparan materi dimensi tiga dikatakan efektif karena total respon positif $>70 \%$, yaitu sebanyak 26 orang $(96,3 \%)$

Aktivitas siswa dari lima siswa yang menjadi fokus, diketahui bahwa dari 8 jenis kategori aktivitas yang diamati diperoleh total rata- rata untuk 7 kategori aktivitas siswa yang dikehendaki dalam KBM sebesar 36,9\% artinya aktivitas siswa pada pembelajaran dengan penggunaan aplikasi Wingeom dalam pemaparan materi pelajaran dimensi tiga berada pada kategori sangat aktif. 
Dalam hal pengelolaan pembelajaran, tingkat kemampuan guru dalam mengelola pembelajaran masuk ke dalam kategori sangat baik dengan perolehan skor 3,512 dan dapat dikatakan bahwa pengelolaan pembelajaran dengan pemanfaatan media berupa aplikasi Wingeom mencapai tingkat keefektifan pengelolaan pembelajaran.

Ini berarti bahwa aplikasi Wingeom dalam pemaparan materi pelajaran dimensi tiga efektif digunakan karena telah memenuhi 4 indikator keefektifan pembelajaran meliputi efektivitas hasil belajar siswa, ketercapaian keefektifan aktivitas siswa, respon siswa terhadap pembelajaran yang positif dan ketercapaian efektivitas kemampuan guru mengelola pembelajaran.

\section{KESIMPULAN}

Berdasarkan penelitian yang telah dilaksanakan dapat diambil kesimpulan sebagai berikut : (1) Hasil belajar siswa setelah penggunaaan aplikasi Wingeom dalam pemaparan materi pelajaran dimensi tiga yaitu mencapai tingkat efektivitas hasil belajar dengan ketuntasan klasikal yaitu sebesar 92,59\% > batas ketuntasan klasikal (85\%); (2) Respon siswa saat proses pembelajaran berlangsung dengan penggunaan aplikasi Wingeom dalam pemaparan materi dimensi tiga dikatakan efektif karena total respon positif dan sangat positif $>80 \%$, yaitu sebesar $96,3 \%$ atau sebanyak 26 orang; (3) Aktivitas siswa saat proses pembelajaran berlangsung dengan pemaparan materi pelajaran dimensi tiga menggunakan aplikasi Wingeom dari lima siswa sebagai perwakilan yang menjadi fokus, diketahui bahwa aktivitas siswa dikatakan efektif karena rata- rata total presentase aktivitas siswa dalam KBM (tujuh kategori aktivitas siswa yang dikehendaki) mencapai kategoro sangat aktif dengan presentase sebesar 96,3\%; (4) Keterlaksanaan pembelajaran dengan pemaparan materi pelajaran dimensi tiga menggunakan aplikasi Wingeom mencapai tingkat keefektifan pengelolaan pembelajaran dengan kategori sangat baik dengan perolehan skor 3,512; dan (5) Aplikasi Wingeom efektif digunakan dalam pemaparan materi pelajaran dimensi tiga dalam proses pembelajaran karena telah memenuhi 4 indikator keefektifan pembelajaran meliputi efektivitas hasil belajar siswa, ketercapaian keefektifan aktivitas siswa, respon siswa terhadap pembelajaran yang positif dan ketercapaian efektivitas kemampuan guru dalam mengelola pembelajaran.

\section{DAFTAR PUSTAKA}

Arcat, A. (2014). Peningkatkan kemampuan spasial siswa SMP melalui model kooperatif STAD berbantuan wingeom. $E d u$ Research, 3(1), 58592.

Faradhila, N. (2013). Eksperimentasi Model Pembelajaran Missouri Mathematics Project (MMP) pada Materi Pokok Luas Permukaan Serta Volume Prisma dan Limas Ditinjau dari Kemampuan Spasial Siswa Kelas VIII Semester Genap SMP Negeri 2 Kartasura Tahun Ajaran 2011/2012.

Novitasari, D., \& Abdul Rahman, A. (2015). Profil kreativitas siswa dalam pemecahan masalah matematika ditinjau dari kecerdasan visual spasial dan logis matematis pada siswa SMAN 3 makasar. Daya Matematis: Jurnal Inovasi 
Pendidikan Matematika,3(1), 4150.

Putra, H. D. (2013). Pembelajaran geometri dengan pendekatan SAVI berbantuan wingeom untuk meningkatkan kemampuan generalisasi matematis siswa SMP. In Prosiding Seminar Nasional Matematika dan Pendidikan Matematika STKIP Siliwangi Bandung (Vol. 1 ). 